Mundo Agrario vol. 18, n 37, e045, abril 2017. ISSN 1515-5994

Universidad Nacional de La Plata.

Facultad de Humanidades y Ciencias de la Educación.

Centro de Historia Argentina y Americana

\title{
La política agraria del kirchnerismo. Entre el espejismo de la coexistencia y el predominio del agronegocio
}

\author{
Rural politics in Kirchnerism. Coexistence or agribusiness \\ predominance?
}

Virginia Toledo López *

* Grupo de Estudios Ambientales - Instituto de Investigaciones Gino Germani, Universidad de Buenos Aires, Argentina | vtoledolopez@gmail.com

\section{PALABRAS CLAVE}

Sustentabilidad

Agronegocio

Políticas agrarias

Argentina

Kirchnerismo

\section{KEYWORDS}

Sustainability

Agronegocio

Políticas agrarias

Argentina

Kirchnerismo

\section{RESUMEN}

El presente artículo examina la denominada “perspectiva neodesarrollista” hacia el agro, considerando su relación con el período anterior. El objetivo es discernir las tendencias imperantes y los enfoques de política dominantes en el sector en el período 2003-2015. Primero se caracteriza el patrón de acumulación de la etapa inaugurada con fin de la convertibilidad. Luego se profundiza en el análisis de la política rural, especialmente observado el Plan de gobierno (PEA 2020) y su dimensión de sustentabilidad. Se pretende así contribuir a la discusión sobre el desarrollo y la sustentabilidad en la Argentina contemporánea a partir del estudio de las políticas desplegadas hacia el sector rural.

\section{ABSTRACT}

This article examines the "neo-developmental perspective" towards agriculture, compared to the previous period. The aim is to recognized the prevailing trends and key policy approaches in the sector, between 2003-2015. First, it characterizes the accumulation pattern, iniciated by the end of convertibility. Then, it analyzes the rural policy, especially observing a governmental plan (PEA 2020) and its sustainability dimension. Thu, through the study of rural policies, we hope to contribute to the discussion on development and sustainability in actual Argentina. 


\section{Introducción}

El neoliberalismo implicó para nuestro país, al igual que para la mayoría de los países latinoamericanos, una exacerbación del sesgo extractivo-exportador del patrón de acumulación a partir de una política macroeconómica sustentada en la convertibilidad. En el mundo rural, la desregulación y el corrimiento del estado estuvieron determinados por la sanción del Decreto ํo 2.284 de fines de 1991, conocido como "de Desregulación”, que consumó el criterio del mercado como parámetro predominante en las políticas públicas hacia el sector (Teubal, 2006, p. 76). A partir de entonces, la profundización del extractivismo ocurrió en sintonía con la expansión del modelo de agricultura industrial y el afianzamiento de la lógica del agronegocio, transformando sustancialmente la naturaleza del agro argentino con grandes externalidades sociales y ambientales.

$\mathrm{Al}$ respecto, vale realizar dos precisiones conceptuales. Por un lado, algunos autores han interpretado al avance de la frontera agropecuaria y la expansión del modelo de agricultura industrial como parte de un proceso de "acumulación por desposesión" o "por despojo", noción derivada del concepto marxista de “acumulación originaria” (Harvey, 2004). Nominativos como "agricultura minera” (Pengue, 2005) dan cuenta de la agricultura industrial en tanto una actividad extractiva, enfatizado en la cantidad de minerales y nutrientes que extrae del suelo sin ningún tipo de reposición ni compensación, destruyendo su estructura y agotándolos; esto intenta ser "solucionado" por el modelo mediante fertilizantes químicos derivados de combustibles fósiles, retroalimentando el extractivismo. Por otro lado, se interpreta al modelo del agronegocio en tanto lógica de funcionamiento y organización del sistema agroalimentario (Gras y Hernández, 2013), cuya característica distintiva será la búsqueda de valorización, más allá de las particularidades de cada una de sus manifestaciones. Así, el esquema productivo no estaría definido ni por un actor ni por un tipo de cultivo, remitiéndose más bien a una forma de producción, valorización y organización que imprime el rumbo de los ámbitos rurales. De esta forma, se asume que las transformaciones operadas en las últimas décadas en distintos niveles del sistema agroalimentario argentino, que llevaron a establecer el predominio de la lógica del agronegocio, potenciaron los aspectos netamente extractivos del modelo agrario (Giarraca y Teubal, 2013).

La devaluación del tipo de cambio en 2002 y la estructuración de una alianza hegemónica en torno de un nuevo proyecto socioeconómico propició cambios en las reglas de juego, que modificarían en parte las políticas hacia el sector. Esto último quedó especialmente plasmado una década después, con la sanción del Plan Estratégico Agroalimentario 2020 (en adelante, PEA 2020). No obstante, la observación y el seguimiento crítico de algunas acciones de gobierno permiten advertir puntos de continuidad con la política precedente.

El presente trabajo explora las políticas hacia el agro durante el kirchnerismo (2003-2015) en aras de dilucidar tanto las tendencias imperantes como las estrategias de desarrollo promovidas hacia el sector, considerando su relación con el período inmediatamente anterior. Con este fin en primer lugar se describen brevemente algunos de los pilares del patrón de acumulación inaugurado en la posconvertibilidad. En segundo lugar, se analizan acciones y políticas hacia el agro, puntualizando en el PEA 2020. Finalmente, se profundiza en la discusión sobre los enfoques de sustentabilidad subyacentes a las mismas. De este modo, se pretende en última instancia contribuir a la discusión sobre el desarrollo y la sustentabilidad en la Argentina contemporánea a partir del estudio de las políticas desplegadas hacia el sector rural.

Para la realización de este estudio se recurrió a estadísticas, informes de organismos y documentos oficiales, información periodística y bibliografía especializada, complementando técnicas cualitativas y cuantitativas de análisis de datos. 


\section{Hacia una definición de neodesarrollismo}

El agotamiento definitivo del patrón de acumulación basado en la valorización financiera se produce a partir de la crisis de la convertibilidad en 2001 (Arceo et al., 2010). A partir de este momento la continuidad del capitalismo en Argentina requirió la generación de un nuevo proyecto sociopolítico, que cobrará mayor definición a partir de la asunción de Néstor Kirchner como presidente en mayo de 2003 (con la continuidad en el rumbo económico marcada por la permanencia en el Ministerio de Economía de Roberto Lavagna).

La nueva etapa estará signada por fuertes cambios, pero también por continuidades en relación a la etapa socioeconómica previa. Principalmente se advierte un cambio en relación a las políticas públicas, particularmente las sociales, articuladas en torno de un discurso que enfatiza en el empresariado nacional y en la expansión del mercado interno como principales dinamizadores económicos. En relación a este último punto, se han despertado profundos debates sobre cuál fue el "motor" de la nueva fase de crecimiento. Algunos autores enfatizan en el papel de la demanda interna, postulando que fue la inversión y el consumo doméstico, tanto público como privado, los que explican el 90\% del aumento del crecimiento entre 2002 y 2008 (Arceo et al., 2010, p. 23). Así, destacan que entre 2003 y 2008 "la economía argentina se expandió a una tasa anual acumulativa del 8,5\%, creando algo más de 4 millones de puestos de trabajo" (Arceo et al., 2010, p. 20). En principio esta afirmación verificaría el carácter trabajo-intensivo del nuevo régimen de acumulación al tiempo que expresa la importancia que tuvo el aumento del empleo en la reactivación del consumo interno y su rol como dinamizador económico. Por su parte, otros autores han revisado este postulado contextualizando y caracterizando ese consumo. Así, asumen como punto de partida el reducido consumo popular existente durante la etapa neoliberal (compensada estructuralmente por las exportaciones, el endeudamiento, la inversión especulativa y el consumo suntuario), y consideran que la devaluación propició un nuevo deterioro, por la gran transferencia de ingresos hacia el capital que significó. Por ello Féliz y López (2012) alegan que "la posterior recuperación del consumo popular en relación a la riqueza total producida fue muy tenue y se ubicó -en promedio- entre 2003-2010 sólo un punto porcentual por encima del promedio que había alcanzado en 1993-2002” (p. 48).

Por otra parte, se advierte que durante todo el período se mantiene un impulso sostenido devenido sobre todo de la demanda externa de materias primas y sus altos precios internacionales. Según Féliz y López (2012, p. 49) en la etapa inaugurada con la devaluación "una porción muy elevada de la riqueza se realiza a través del comercio exterior y es esta dinámica la que permite las elevadas tasas de crecimiento del PBI”. Ello se liga además con la débil transformación de los patrones de inserción internacional, lo cual se advierte en la figura 1.En este sentido se ha remarcado el sesgo neoextractivista del nuevo modelo. ${ }^{1}$

La figura 1 da cuenta de la participación de los diferentes complejos en el total de dólares ingresado por las exportaciones, advirtiéndose el rol fundamental de las actividades recurso-naturales intensivas. Tal como se desprende de la tabla, a pesar de que la salida devaluacioncita significó un revés al enfoque monetarista o de valorización financiera y de que el comercio exterior adquirió un renovado dinamismo, se advierte que las exportaciones no cambiaron su perfil sectorial. Al contrario, aumentaron su concentración en un número reducido de rubros, destacándose los intensivos en bienes naturales (como lo son el petróleo, los agrícolas o el pesquero). A ello se agrega que en muchos casos la industrialización se remite a las primeras etapas de transformación de las materias primas, lo cual retroalimenta el patrón de especialización internacional. Por ejemplo, "en el bienio 2007-2008 sólo cinco sectores fabriles dieron cuenta de $85 \%$ de las ventas externas totales, frente a una participación algo superior a 78\% en el periodo 1993-2001: industria alimenticia, sector automotor, refinación de petróleo, elaboración de productos y sustancias químicas, y manufactura de metales comunes (siderurgia y aluminio primario)" (Azpiazu y Schorr, 2010,p. 129). En este marco se relativiza el aumento de la producción industrial, dado el similar incremento visualizado en las actividades extractivorentistas. Según Féliz y López (2012,p. 50) “entre 1997 y 2010 el crecimiento en el valor agregado en la 
producción de mercancías no elaboradas del complejo agro-minero fue similar al aumento en la producción de valor de la industria manufacturera: $37,7 \%$ versus $38,9 \%$, respectivamente". Por tanto se afirma que el cambio más importante en relación a la década previa está asociado a la mejora sustancial de la competitividad en el precio de las exportaciones, manteniendo su perfil sectorial.

Figura 1: Exportaciones según complejos exportadores de Argentina. Años 1997 - 2006 (Participación porcentual)

\begin{tabular}{|c|c|c|c|c|c|c|c|c|c|c|}
\hline \multirow{2}{*}{$\begin{array}{c}\text { Complejos } \\
\text { exportadores }\end{array}$} & 1997 & 1998 & 1999 & 2000 & 2001 & 2002 & 2003 & 2004 & 2005 & 2006 \\
\hline & \multicolumn{10}{|c|}{ \% sobre el total de las exportaciones } \\
\hline $\begin{array}{l}\text { Principales } \\
\text { Complejos }\end{array}$ & 83,6 & 83,0 & 80,9 & 81,1 & 81,0 & 83,0 & 84,0 & 84,1 & 84,1 & 82,1 \\
\hline Oleaginoso & 17,9 & 21,0 & 21,6 & 18,5 & 20,4 & 22,9 & 26,8 & 24,5 & 23,1 & 21,4 \\
\hline Petroquímico & 13,2 & 10,1 & 13,8 & 19,5 & 18,8 & 19,9 & 20,2 & 19,9 & 19,9 & 18,5 \\
\hline Cerealeros & 12,6 & 12,5 & 9,4 & 9,8 & 9,8 & 9,0 & 8,5 & 8,5 & 7,6 & 7,1 \\
\hline Automotriz & 12,1 & 13,1 & 8,8 & 9,1 & 8,9 & 7,6 & 5,9 & 7,3 & 8,5 & 10,0 \\
\hline De origen bovino & 8,5 & 7,2 & 8,2 & 7,1 & 5,2 & 5,9 & 5,6 & 7,2 & 7,3 & 6,7 \\
\hline Frutihortícolas & 4,4 & 4,6 & 4,3 & 3,3 & 3,8 & 3,2 & 3,3 & 3,2 & 3,4 & 3,4 \\
\hline Pesquero & 3,9 & 3,5 & 3,5 & 3,2 & 3,6 & 2,8 & 3,0 & 2,4 & 2,0 & 2,7 \\
\hline Siderúrgico & 3,5 & 3,3 & 3,0 & 3,4 & 3,6 & 4,3 & 3,5 & 3,4 & 4,2 & 3,8 \\
\hline $\begin{array}{l}\text { De origen } \\
\text { forestal }\end{array}$ & 2,0 & 1,8 & 1,9 & 1,9 & 1,6 & 1,9 & 2,1 & 2,3 & 2,0 & 2,0 \\
\hline Cobre & -- & 1,7 & 1,8 & 1,3 & 1,4 & 1,8 & 1,6 & 1,9 & 2,5 & 2,9 \\
\hline Aluminio & 1,0 & 0,8 & 1,0 & 1,5 & 1,3 & 1,4 & 1,3 & 1,1 & 1,1 & 1,0 \\
\hline Uva & 1,0 & 0,9 & 1,1 & 1,0 & 0,9 & 0,9 & 0,9 & 1,1 & 1,3 & 1,3 \\
\hline Tabacalero & 0,8 & 0,6 & 0,8 & 0,6 & 0,6 & 0,6 & 0,5 & 0,6 & 0,5 & 0,5 \\
\hline De origen ovino & 0,7 & -- & 0,5 & 0,5 & 0,5 & 0,6 & 0,6 & 0,6 & 0,5 & 0,4 \\
\hline Algodoneros & 1,8 & 1,3 & 1,1 & 0,4 & 0,5 & 0,3 & 0,2 & 0,2 & 0,3 & 0,2 \\
\hline Resto & 16,4 & 17,0 & 19,1 & 18,9 & 19,0 & 17,0 & 16,0 & 15,9 & 15,9 & 17,9 \\
\hline Total & 100 & 100 & 100 & 100 & 100 & 100 & 100 & 100 & 100 & 100 \\
\hline
\end{tabular}

Fuente: INDEC. Complejos exportadores (acceso el 1/2/2009).

Entonces es posible sostener, a modo de síntesis preliminar, que el ciclo de crecimiento estuvo fuertemente basado en la recuperación de la capacidad productiva instalada y amparado en un tipo de cambio competitivo, en un contexto externo favorable, lo cual habilitó una expansión de las exportaciones, al tiempo que se producía la recuperación de los salarios y la ampliación de la demanda interna promoviendo mejoras socioeconómicas en la población. Por su parte, el nuevo perfil de políticas involucró una gran expansión del gasto público (sustentado por el superávit fiscal), lo cual expresó un distanciamiento claro en relación al enfoque de la década neoliberal y permitió incrementar las condiciones de legitimidad del proyecto hegemónico. Según Balsa (2013, p. 29) la ampliación del consumo jugó un rol clave en el nuevo programa político en tanto "elemento articulador de consensos", en sintonía con lo ocurrido en la década de los noventa. Por último, el dinamismo en el sector externo significó un fuerte movimiento en los demás sectores económicos y una mejora de ciertas condiciones sociales, sin traducirse en un cambio estructural (Azpiazu y Schorr, 2010).

El ciclo de crecimiento encontró un techo en la etapa que se abrió a mediados de 2007, cuando a raíz del proceso de inflación y apreciación de la moneda se neutralizaron los incrementos salariales, incentivando una 
tendencia a la disminución del salario real y acrecentando la explotación laboral, impidiendo de esta forma una mejora significativa de la distribución del ingreso. En efecto, "a la vez que se estancaban las remuneraciones de los trabajadores producto de la inflación, la productividad por ocupado continuó su ritmo ascendente, determinando la apropiación de ganancias extraordinarias por parte del sector empresario" (Arceo et al., 2010, pp. 31-32). Estos factores internos confluyeron con una variación en el contexto internacional (por la crisis financiera y el colapso económico internacional) a mediados del 2008. Todo ello supuso una desaceleración del crecimiento económico y un necesario reajuste en el modelo a fin de mantener los "logros" (esto es, las mejoras socioeconómicas en relación a la etapa neoliberal). Sin embargo, en tanto el saldo comercial y el gasto público continuaron incrementándose (Arceo et al., 2010, p. 37),los efectos de la crisis se vieron morigerados, pese a lo cual se revelaron algunas limitaciones del modelo (tanto por características heredadas como por sus fragilidades estructurales).Por un lado, la necesidad de mantener un tipo de cambio competitivo en el contexto de crisis impuso límites a la expansión del mercado de trabajo, tanto en lo que se refiere a la creación de nuevos puestos como a los incrementos de salario(a partir del 2008 se revirtió la tendencia descendente de la tasa de desocupación), al tiempo que la inflación (generada por la mayor liquidez, la creciente demanda interna y las pujas por la apropiación de los excedentes, entre otras variables) presionaba la apreciación de la moneda local (Arceo et al., 2010, p. 43). Así, en principio la crisis reveló el rol nodal del tipo de cambio y de la política salarial como rasgos distintivos del proyecto socioeconómico y político kirchnerista. Por otro lado, la crisis internacional no involucró una transformación del sesgo extractivo-exportador. A decir de Svampa (2012, p. 17), “aún en un contexto de crisis económica y financiera internacional, que anuncia mayor incertidumbre y volatilidad de los mercados, las economías latinoamericanas continúan con un desempeño positivo: así, los datos de 2011 proyectaban una tasa de crecimiento del PIB regional del 4,7\%, contra el 6\% de 2010”.

Figura 2: Primeros diez complejos exportadores de Argentina (millones de dólares)

\begin{tabular}{|l|c|c|c|c|c|}
\hline \multirow{2}{*}{ Principales complejos exportadores } & \multicolumn{5}{|c|}{ Años } \\
\cline { 2 - 6 } & 2007 & 2008 & 2009 & 2010 & 2011 \\
\hline Complejo oleaginoso & 14.401 & 18.394 & 13.964 & 18.079 & 22.014 \\
\hline Complejo soja & 13.605 & 16.609 & 12.990 & 17.317 & 20.561 \\
\hline Complejo girasol & 764 & 1.729 & 934 & 721 & 1.367 \\
\hline Otras exportaciones oleaginosas & 32 & 57 & 40 & 42 & 86 \\
\hline Complejo automotriz & $\mathbf{6 . 0 1 0}$ & 7.247 & 5.982 & 8.620 & 10.627 \\
\hline Complejos cerealeros & 5.243 & 7.662 & 3.931 & 5.417 & 9.426 \\
\hline Complejos petrolero-petroquímico & 7.679 & 8.510 & 6.772 & 7.213 & 7.388 \\
\hline Complejos de origen bovino & 3.236 & 3.522 & 3.230 & 3.276 & 3.944 \\
\hline Complejos frutihortícolas & 1.805 & 2.334 & 1.910 & 2.259 & 2.669 \\
\hline Complejo oro & 573 & 704 & 1.042 & 2.014 & 2.327 \\
\hline Complejo siderúrgico & 1.955 & 2.326 & 1.702 & 1.570 & 1.869 \\
\hline Complejo pesquero & 1.108 & 1.304 & 1.129 & 1.344 & 1.481 \\
\hline Complejo cobre & 1.496 & 1.137 & 1.135 & 1.514 & 1.406 \\
\hline Total general & 55.980 & 70.019 & 55.672 & 68.187 & 83.950 \\
\hline
\end{tabular}

Fuente: INDEC 
Tal como muestra la figura 2, si bien en el 2009 se registró una disminución en todas las ventas externas las mismas se recuperan inmediatamente al año siguiente. También deja advertir que, en el 2011, de 83.950 millones de dólares que ingresaban por exportaciones poco más del 26\% era de oleaginosas (y el 24,4\% de soja y sus derivados). De este modo, en el período 2007-2011 también se advierte la profundización en la primacía de los complejos exportadores intensivos en bienes naturales.

En síntesis, retomando al razonamiento de Féliz (2012,p. 17), se enfatiza en "el rol estratégico de las ramas extractivistas (particularmente, producción de soja y minería a cielo abierto) y la precarización laboral como elemento estructural” del programa socioeconómico de la posconvertivilidad.En este marco, se define al mismo como "neodesarrollista" (Féliz y López, 2012, pp. 66-70), cuyos pilares en una etapa inicial fueron: (a) el sostenimiento de un tipo de cambio estable y competitivo junto a una tasa de interés moderadabaja, $\underline{\underline{2}}(\mathrm{~b})$ el crecimiento salarial (no mayor al crecimiento de la productividad laboral), $\underline{\underline{3}}$ (c) superávit fiscal del Estado (que incluye prácticas fiscales "responsables" a la par que se controla el endeudamiento externo)complementado con una política anticíclica fundada en la expansión del gasto público (en sintonía con el nuevo perfil de políticas públicas).

El fundamento teórico del neodesarrollismo se encuentra en el (neo)estructuralismo, ${ }^{4}$ con algunos rasgos distintivos (Féliz y López, 2012). La principal diferencia con el estructuralismo cepalino que fundamentó el desarrollismo implementado en Argentina entre los cincuenta y sesenta, estará en la influencia que tiene en la actualidad el mercado externo en el proceso de acumulación. Así, en el neodesarrollismo las políticas estarán orientadas especialmente a fomentar los encadenamientos productivos en torno a las industrias exportadoras, en un contexto externo favorable. Por tanto, si bien se mantiene la retórica mercado internista y el fomento a la industrialización, actualmente la acumulación se sostiene "fundamentalmente sobre la base del crecimiento exportador”, reforzando el sesgo extractivo (Féliz, 2012, p. 18). Así, “si antes la propuesta era el crecimiento 'hacia adentro' -hacia el mercado interno-, hoy el planteo es el crecimiento 'desde dentro' hacia el comercio exterior-” (Féliz y López 2012, p. 67).

Hacia el 2008 se inicia una nueva fase en el proyecto neodesarrollista, marcada tanto por el contexto de crisis internacional como por las tensiones propias de las contradicciones internas. En particular, el proceso sostenido de apreciación de la moneda, en especial en relación al dólar, y el limitado desarrollo de la productividad laboral socavó las posibilidades de sostener el tipo de cambio “alto/competitivo/estable”. La nueva fase del neodesarrollismo tendrá como característica "la tendencia al deterioro del tipo de cambio real estructural que redunda en una sostenida caída en la competitividad del capital local” (Féliz, 2015a, p. 71). Asimismo, las persistentes dificultades fiscales propiciaban límites evidentes a la redistribución progresiva de los ingresos. Los recursos entonces fueron la ampliación de la deuda (primero con agencias nacionales y progresivamente el endeudamiento externo) en paralelo a que se refuerzan los acuerdos con China y Rusia. Además, se profundiza la proyección de políticas de planificación a mediano plazo que buscan institucionalizar y consolidar las bases de la acumulación de capital en el neodesarrollismo: la industrialización y el neoextractivismo (Feliz, 2015). De allí la sanción de planes estatales para sectores específicos, entre los cuales observaremos en particular el PEA 2020.

A continuación se analizarán algunos acontecimientos clave ocurridos en el campo de las políticas públicas hacia el agro, enfatizando en el PEA 2020, a fin de discernir el enfoque neodesarrollistahacia el mundo rural. Los ejemplos mencionados han sido seleccionados por su grado de difusión pública y porque muestran conflictos de intereses respecto del mundo rural y su proyección política. 


\section{El neodesarrollismo en el agro}

\section{Profundización del proceso de sojización}

Las transformaciones ocurridas en el sector agropecuario argentino en el sentido del predominio del modelo del agronegocio (Gras y Hernández, 2013) tuvieron un punto de inflexión a mediados de la década de los noventa, cuando se liberó la comercialización de la semilla de soja RR. Este evento habilitó la adopción generalizada del nuevo paquete tecnológico compuesto por el método de siembra directa y el uso de variedades modificadas genéticamente resistentes a herbicidas, como el glifosato (en el caso de la soja RR, ambos de la misma empresa). El balance entre unos costos de cultivo inicialmente bajos, $\underline{5}$ la fuerte demanda externa de oleaginosas y el altísimo precio de la soja en los mercados internacionales (a lo que se sumó el tipo de cambio favorable desde el abandono de la convertibilidad a comienzos del 2002), derivó en que nuestro país pasara a tener en pocos años el porcentaje más alto de cultivo de soja transgénica en el mundo (aprox. el 90\%). La soja se convirtió en el principal cultivo anual, tanto en su área sembrada como en su producción (Teubal, 2003; 2009). Con la posterior aprobación de otros cultivos transgénicos, encabezados por el maíz, esta lógica se trasladó a otras producciones. Así, con el nuevo esquema agrícola un grupo reducido de cultivos (principalmente maíz y soja), que se encontraban concentrados hasta entonces en la región pampeana y cuya producción se destinaba principal -aunque no exclusivamente- al mercado externo, aumentaron significativamente su área sembrada. El incremento en la producción de estos cultivos fue posible tanto gracias a la intensificación, por una mayor participación de la ciencia y técnica en el proceso productivo que permitió una mayor productividad por hectárea, como a la incorporación de nuevas tierras a la producción: en 1988 la superficie en uso productivo era de 30.766.460,5 ha, que pasaron a 33.491.480,2 ha en 2002 (una diferencia de 2.725.020 ha).

El gráfico muestra la expansión de la superficie sembrada con soja, especialmente a partir de la difusión del evento transgénico. Este fenómeno denominado por los especialistas como "sojización", ha sido ampliamente estudiado, tanto a nivel del país como a nivel regional o local (Pengue, 2005; Teubal, 2003, 2009; Tort, 2004; Paruelo, Guerschman y Verón, 2005; Domínguez y Sabatino, 2006; entre otros). Varios de estos estudios han destacado el avance de este cultivo a zonas extrapampeanas, en especial en el noroeste y noreste del país.

\section{Figura 3: Superficie sembrada con soja en Argentina. Período 1995-2015 (en hectáreas)}

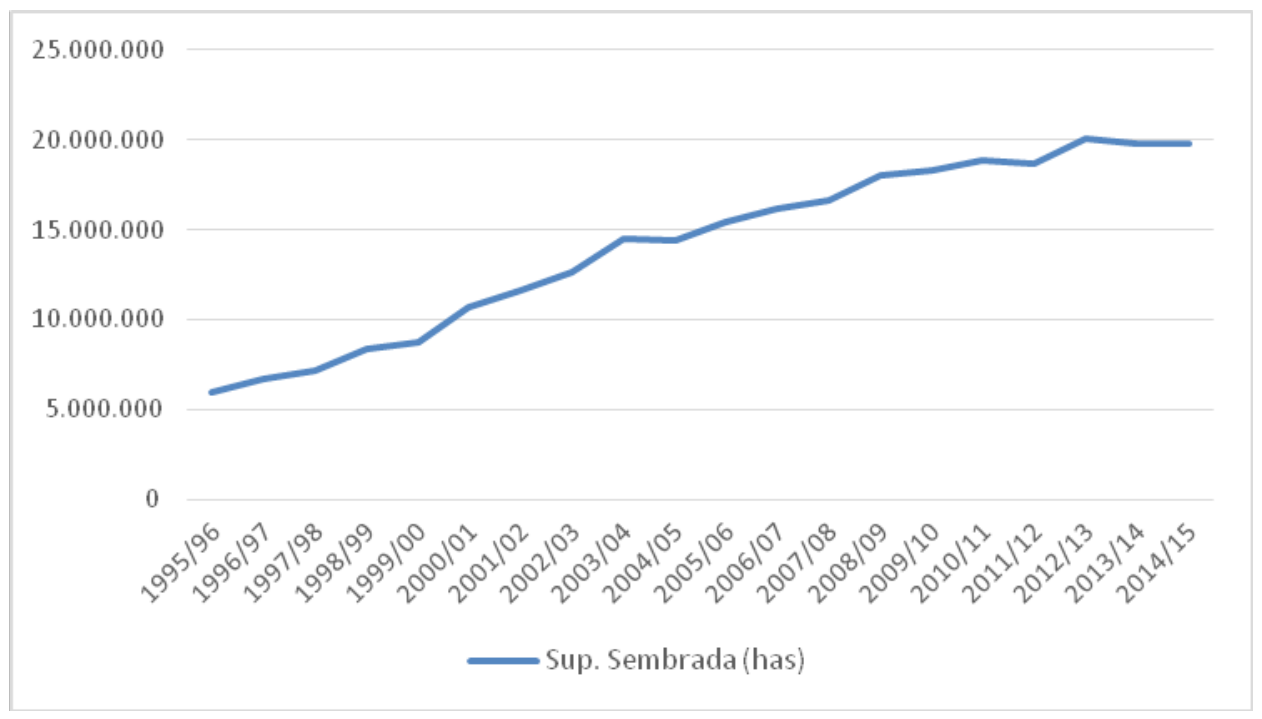

Fuente: SIIA.

Se advierte que entre 1996 y 2002 el área sembrada con soja se duplicó. Gras y Hernández (2013) puntualizan a esta etapa como la primer fase de expansión de la lógica del agronegocio, postulando que en 
ella se advierte una menor diversificación productiva fortaleciendo la especialización y desplazando otros usos del suelo. Ello favorece una tendencia a la monoproducción, al tiempo que impulsa el despliegue de actividades con escasa vinculación con los entramados productivos locales. Durante la década kirchnerista la abrupta expansión de la superficie sembrada con sojacontinuó, alcanzando recientemente los 20 millones de hectáreas, tal como muestra el gráfico. Asimismo, entre 2003 y 2015la superficie sembrada con soja en todo el país creció un 136\% y la producción un 194\%.Es en las provincias "extra-pampeanas" donde se presenta con mayor potencia el avance de la expansión sojera, registrándose un aumento del 227\% en la superficie ocupada con soja (mientras que en la zona pampeana se duplicó).En la zona pampeana, en la que se ubica el 80\% de la soja cultivada, en el 2000 la superficie sembrada era de 7.775 .000 ha y en el 2011 pasó a 15.565.569 ha. En las extrapampeanas pasó de 1.015.000 ha en 2000 a 3.321.065 ha en 2011 (Martínez Dounac, 2013, p. 334). Se advierte entonces que el proceso de sojización se profundiza durante el neodesarrollismo, expansión que conlleva la creciente homogenización en los paisajes rurales y el predominio del modelo del agronegocio.

En segundo lugar se destaca el paralelo crecimiento de la elaboración de aceite de soja (llegando en 2010 a 6,9 millones de toneladas), lo cual puede comprenderse en el marco general de promoción de la (agro) industrialización, propio del neodesarrollismo (lo que será profundizado con del análisis del PEA 2020 en el apartado siguiente). A priori señalamos que esto será una característica distintiva de la etapa, denotando el comienzo de una nueva fase en el proceso de sojización.

En tercer lugar, y retomando lo antes señalado en relación al sesgo primario exportador, se observa durante el neodesarrollismo un aumento en las exportaciones del complejo (a una tasa anual promedio del 12,6\%), alcanzando en 2010 los 18.174 millones de dólares (MECON, 2011). Por lo demás, el aumento excepcional de los precios internacionales de los commodities agrícolas a partir del año 2007, posibilitó un elevado nivel de rentabilidad para el sector, gracias al mantenimiento de un tipo de cambio alto y una nueva reducción de los costos de producción (Puechagut, 2012, p. 8).Así, la renta de la tierra agraria asume un rol destacado en el modelo de acumulación de este período (Kornblihtt, Seiffery Mussi, 2015).

\section{Creciente conflictividad territorial}

Durante el neodesarrollismo también se profundiza la presión por la tierra, lo cual intensifica la conflictividad. Este fenómeno se encuentra vinculado a la expansión del agronegocio, ya que el sistema productivo por este difundido involucra la producción en escala (siendo los suelos un recurso finito), la mercantilización de los vínculos (con un fuerte auge del contratismo) y la creciente participación del capital financiero (evidenciando un cambio significativo respecto de su comportamiento histórico) (Gras y Hernández, 2013). Asimismo, se asocia a la continuidad en la tendencia alcista en el precio de la tierra, señalada por Martínez Dounac (2013) como un factor derivado de la persistente concentración económica y territorial en torno de los grandes grupos empresarios y que se enmarca en el proceso global de acaparamiento de tierras o land-grabbing, relativo a las transacciones de tierra a gran escala, que ha llevado a un aumento inusitado de su precio. Por su parte, Gras y Hernández (2013, pp. 39-40) han destacado que en Argentina este fenómeno adquiere algunas particularidades. Por un lado, además de ser receptor de las “inversiones" realizadas por las firmas privadas transnacionales (integradas por más de un grupo inversor y que pueden ser de distintos países), posee grupos empresarios nacionales (como El Tejar, Adecoagro, Cresud, entre otros) que participan del proceso de acaparamiento de tierras dentro y fuera de las fronteras del país (siendo uno de los factores que explican la expansión del agronegocio a los países limítrofes del Cono Sur). Por otro lado, según las autoras, en nuestro país el fenómeno de acaparamiento se manifiesta también a través del arrendamiento, dadas las características que ha adquirido el agro argentino en las últimas décadas. Finalmente, el proceso se asocia al interés de mejorar el posicionamiento en los principales cultivos 
exportables, por tanto, se produce tanto en áreas donde la agricultura capitalista tiene largo asiento como en las áreas de incorporación reciente y de frontera productiva.

En esta línea de análisis, la importancia de la renta de la tierra en el patrón de acumulación neodesarrollista se visualiza también en el acrecentamiento de las disputas por su apropiación (Varesi, 2016). Algunos ejemplos ilustran este incremento de la conflictividad: por un lado, en sólo dos años fueron asesinados cuatro militantes por la defensa del territorio. ${ }^{6}$ Por otro, se destacan las crecientes protestas por las fumigaciones en zonas periurbanas, cuya referencia fue la campaña «Paren de Fumigar» iniciada en Córdoba a partir del caso de las madres del barrio Ituzaingó-Anexo. ${ }^{7}$ Estas protestas derivaron en la sanción de ordenanzas y proyectos provinciales (como en el caso de Buenos Aires) que establecen zonas de exclusión para el uso de

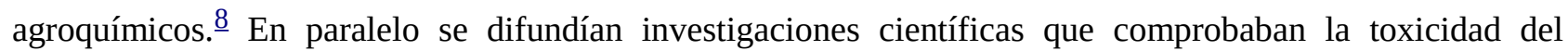
principal herbicida del paquete tecnológico de la soja (glifosato), promoviendo un debate sobre el conocimiento científico que adquirió dimensión pública (incorporando crecientemente elementos epistemológicos y ontológicos a la discusión). $\underline{9}$

Así, la creciente conflictividad asociada a la defensa de los bienes de la naturaleza constituye una característica de esta etapa y es interpretada como una expresión de la resistencia social frente al (neo) extractivismo en general y al avance del agronegocio en particular, que fue crecientemente reprimida. $\underline{10}$

\section{Transformación del enfoque de política pública}

El masivo conflicto desatado tras la divulgación de la Resolución 125/08 del Ministerio de Economía, que pretendía establecer retenciones móviles (que con la cotización vigente en ese momento implicaba un incremento al 44,1\% para la soja), marcó un antes y un después en la política hacia el sector rural. Este hecho terminó por romper la ya deteriorada relación del gobierno con las principales entidades representativas del sector. Tal como relata Barsky (2013), la política hacia el sector estuvo signada desde el principio de la gestión de Néstor Kirchner por las negociaciones en torno de los derechos de exportación, en un contexto de altos precios internacionales de estos productos. Los vínculos comienzan a deteriorarse cuando, tras la designación de Felisa Micheli a cargo del Ministerio de Economía en 2005, comenzaron los roces a partir de los acuerdos para la fijación de un precio (interno) a la carne vacuna. En este contexto el Secretario de Agricultura, Miguel Campos, renuncia asumiendo en su lugar Javier de Urquiza (proveniente de una familia tradicional rural y actualmente vinculada a la agroindustria). Mientras, el gobierno continuó incrementando las retenciones a las exportaciones agrícolas. En un contexto de tensión creciente, el anuncio de Martin Lousteau en marzo de 2008 del esquema de retenciones móviles no fue bien recibido por las entidades del sector. Así, la política hacia el sector durante las administraciones kirchneristas giraron principalmente en torno de la regulación del comercio exterior (mediante la asignación de cupos a algunos productos de consumo popular y el esquema de retenciones) y al reforzamiento del presupuesto para investigaciones del sector (incluyendo el presupuesto del INTA, 2008).

El “conflicto del campo", tal como se lo conoció, contó con una masiva adhesión, visible a través de las múltiples medidas de fuerza realizadas en diversos puntos del país, y significó un cimbronazo a la política neodesarrollista. En principio es preciso considerar, tal como señalan Teubal y Palmisano (2010, p. 194) que de este conflicto quedaron excluidos el sector campesino, indígena y una parte importante de la agricultura familiar. Así, la referencia al "campo” remitía a la Mesa de Enlace, integrada por Confederaciones Rurales Argentinas (CRA), Confederación Intercooperativa Agropecuaria (CONINAGRO), Federación Agraria Argentina (FAA) y la Sociedad Rural Argentina (SRA). No obstante, el contexto de protesta permitió que sectores de medianos productores y chacareros manifestaran sus problemáticas y críticas frente al gobierno, aunque se alejaran del eje de discusión planteado en torno de las retenciones. En todo caso "se generó una 
polarización de posturas que ocultó muchos de los problemas” estructurales que afectan al sector, y al país todo (Teubal y Palmisano, 2010, p. 229). Por otra parte, vale señalar que esa polarización de la discusión tampoco permitió una revisión crítica del funcionamiento de las retenciones en tanto mecanismo redistributivo. $\frac{11}{}$ Por último, significó también un abrupto quiebre en la coalición política gobernante por cuanto, tras más de tres meses de movilizaciones en todo el territorio nacional, la cuestión se resolvió en el Senado con el veto a la propuesta por parte del mismo vicepresidente de la nación, Julio A. Cobos.

Por lo demás, a partir de esta coyuntura se visualizan una serie de acciones que permiten profundizar el análisis del enfoque neodesarrollista hacia el mundo rural. En principio, la propuesta de la creación del Ministerio de Agricultura, Ganadería y Pesca (MAGyP) y el PEA 2020 supusieron un significativo paso en la recuperación de funciones de regulación que el Estado había abandonado en las últimas décadas. De hecho hasta el momento de su elaboración en el país había primado, al decir de Giarracca, una "omisión de política” en relación al agro (en Mikkelsen, 2008, p. 184). Así, el PEA 2020 marcó un punto de quiebre, condensando expresamente la quintaesencia de la estrategia neodesarrollista para el agro, todo lo cual será profundizado en el apartado siguiente.

La transformación en la forma de desplegar políticas hacia el sector se evidenció también en una serie de propuestas legislativas que el gobierno nacional presentó seguidamente, las cuales son interpretadas a priori en el sentido de regular la actividad y revertir algunos de los impactos negativos derivados del predominio del mercado en las decisiones del sector, distanciándose del accionar estatal de la década de los noventa. Se destacan el Régimen de Trabajo Agrario (Ley $N^{\circ}$ 26.727), también conocido como "Estatuto del Peón Rural” $\underline{12}$ y la Ley $\mathrm{N}^{\circ} 26.737$, sobre extranjerización de tierras. $\underline{13}$ Sin embargo, pese al gran impacto que esta última tuvo en términos mediáticos, desde diversos sectores se puso en duda la influencia real de esta Ley en los fenómenos relativos a la concentración territorial y creciente extranjerización. $\underline{14}$

Por último, cabe señalar la sanción en diciembre de 2014 (Año Internacional de la Agricultura Familiar), de la Ley de "Reparación histórica de la agricultura familiar para la construcción de una nueva ruralidad en la Argentina” (Ley N² 27.118), a iniciativa del partido oficialista. La normativa sin dudas aporta al debate sobre qué tipo de modelo agrario se promueve actualmente en el país y cómo se espera que sea la "nueva ruralidad" a construir, incorporando algunas de las demandas de las entidades representativas de la agricultura familiar. Según datos oficiales la agricultura familiar representa el $20 \%$ del PBI del sector agropecuario nacional, el 20\% de tierras productivas (30,9 millones de hectáreas totales), el 27\% del valor de la producción y el 65\% de productores. Asimismo, contribuye con el 53\% del empleo rural (MAGyP, 19 de diciembre de 2014). Entre los puntos más significativos, en cuanto a la incorporación de las demandas históricas del sector, se destaca que la norma considera a la tierra como bien social y crea un Banco de Tierras (Art. 16) para el desarrollo de emprendimientos productivos que promuevan el arraigo rural, de manera articulada con provincias y municipios. En el Art. 19 se promueve una suspensión de los desalojos por tres años y genera una Comisión Nacional Permanente de Regularización Dominial de la Tierra Rural (Art. 18). Del mismo modo garantiza el acceso y funcionamiento de todos los servicios sociales (Art. 30), incluyendo la creación de un seguro integral (Art. 33), así como apoya la diversificación e innovación productiva (Art. 23) y estimula el despliegue de políticas de provisión y mejora de la infraestructura rural (Art. 29), incluyendo líneas de crédito específicas (Art. 33). En este marco la Ley también prevé la promoción de las ferias locales, zonales y nacionales de la agricultura familiar para apoyar el contacto directo entre productores y consumidores. Por su parte, la norma en su Art. 26 genera el Centro de Producción de Semillas Nativas (CEPROSENA), introduciendo un nuevo elemento a la discusión sobre las semillas en Argentina. El organismo tendrá a su cargo la tarea de promover la investigación y la preservación de estas variedades que forman parte del proceso de selección realizado por pueblos originarios, comunidades campesinas y pequeños agricultores. La Ley requiere la ratificación de las provincias para su 
plena vigencia. Por su parte, establece un presupuesto de 1.500 millones de pesos, que difícilmente alcanzarían para una implementación cabal (Ley N²7.118).

\section{Biotecnología y mercantilización de la vida}

Es posible señalar como último elemento característico del enfoque neodesarrollista hacia el agro la fuerte apuesta a la expansión de la biotecnología, en lo que se expresa también el predominio simbólico y material del agronegocio. Esto se evidenció igualmente en la persistente asociación en los discursos oficiales de esta rama del conocimiento con el dinamismo tecnológico y el avance científico; así como también en la reciente reactivación de la discusión sobre su marco legal y en la difusión de nuevos eventos transgénicos. Desde 2011 hasta fines de 2012 se aprobaron 10 eventos transgénicos de maíz y soja, propuestos por Bayer, Monsanto y Syngenta, entre otras (Carrasco, 2012). De esos diez eventos transgénicos aprobados, cinco (3 de maíz y 2 de soja) combinan la resistencia al Glifosato con la del Glufosinato de amonio (un bloqueante de la síntesis del aminoácido glutamina) para reforzar los efectos de aquel. Particularmente, se destaca la aprobación en agosto de 2012 de Intacta RR2 Pro o Bt RR2Y, una nueva variedad de soja transgénica presentada por Monsanto, que además de ser resistente al herbicida tiene efecto insecticida sobre algunas plagas. Este fue el evento número 27 aprobado por el gobierno argentino para su comercialización en el territorio nacional desde el 1996. En paralelo, el Ministro de Agricultura Norberto Yahuar anunció el envío de un proyecto referido a la sanción de una nueva Ley de semillas (contemplado en el PEA 2020), para "demostrar al mundo que se reconoce ese valor intelectual en tecnología, que desarrollan los privados”. $\underline{15}$ El proyecto recibió el apoyo de varias entidades representativas del agronegocio y el rechazo explícito de los sectores asociados a los pequeños productores y agricultores familiares.

Al mismo tiempo que se elevaba este proyecto se producían dos hechos, con epicentro en la provincia de Córdoba, que daban cuenta del impulso a la biotecnología y el patentamiento en el neodesarrollismo como de la continua resistencia social frente al (neo)extractivismo: en agosto de 2012 por un lado se anunció, tras una serie de reuniones concertadas entre Cristina Fernández de Kirchner y funcionarios de primer nivel con directivos de Monsanto, la instalación de la planta más grande de América Latina para la producción de semillas de maíz transgénico (para 3.5 millones de hectáreas) en la localidad de Malvinas Argentinas (a 12 Km de la capital cordobesa), con una inversión de más de 1.500 millones de dólares. La población organizó un bloqueo para evitar la entrada de materiales y la construcción de la planta. El bloqueo continuó pese a los reiterados episodios represivos, logrando frenar el proyecto. Por otro, se conocía el fallo del tribunal cordobés en el primer caso de fumigaciones que llega a juicio penal, a favor de las Madres de Ituzaingó. La sentencia encontró culpables de contaminar y afectar la salud de la población al productor agropecuario y al aerofumigador, que recibieron una pena de tres años de prisión condicional, sin cumplimiento en cárcel.

Por su parte, en mayo de 2015 el Gobierno anunció la firma de un Decreto de Necesidad y Urgencia (DNU) para regular el cobro de regalías extendidas, como exigencia de la empresa Monsanto (sólo consensuado con la Asociación de Semilleros de Argentina, que nuclea a las grandes empresas del sector). Semanas más tarde se anuló la iniciativa, proponiendo un nuevo proyecto de ley en base al texto del DNU que sería enviado al Congreso Nacional (Aranda, 2015). De este modo se reactivó una discusión -que continúa vigente- sobre la protección de las semillas y el avance de la propiedad intelectual sobre los organismos vivos. Según los trascendidos, la propuesta lesiona el derecho de quien reserva y siembra semillas para uso propio, que deja de ser un derecho universal para convertirse en una excepción, incrementando sanciones y otorgando a las empresas el poder de policía para controlar y fiscalizar. De este modo el derecho histórico de los agricultores a guardar, resembrar e intercambiar semillas quedaría acorralado por el control ejercido por las transnacionales. Asimismo, y se puede interpretar que es en este sentido que la Ley de Agricultura Familiar genera el CEPROSENA, limitaba el intercambio o comercialización de semillas no identificadas y 
registradas. De este modo, se profundizaría la dependencia de los agricultores con respecto al mercado nacional, crecientemente dominado por corporaciones semilleras, nacionales y multinacionales.

Por último, hacia fin de su mandato, la presidente junto a Carlos Casamiquela anunció la autorización de dos eventos biotecnológicos para la producción de soja (resistente a la sequía) y de papa (resistentes al virus PVY), enfatizando que de este modo se "coloca a la Argentina entre los seis países que alcanzaron este tipo de desarrollo científico”. $\underline{16}$ En el caso de la soja, el evento que permite mantener los rendimientos en condiciones de carencia temporal de agua, fue creado por un grupo de trabajo de la Universidad Nacional del Litoral (UNL) y del Conicet, e incorporado en soja por el Instituto de Agrobiotecnología Rosario (INDEAR), del grupo Bioceres, que mantiene la licencia de uso y explotación. Ambos eventos fueron justificados por su aporte a la competitividad del sector, al desarrollo de la industria nacional (por tratarse de "un emprendimiento nacional con interacción público-privado”) y a la alimentación. $\frac{17}{}$ Especialmente se remarca, en lo que parece ser un resurgir del discurso que legitimó la Revolución Verde en sus comienzos, las siguientes palabras de Fernandez de Kirchner: "estos no son eventos sólo tecnológicos sino también económicos y sociales que van a producir más alimentos para la humanidad”. $\underline{18}$ Se reedita así el slogan que propició el imperio del sistema agroalimentario corporativo y la expansión de los cultivos genéticamente modificados, según el cual los transgénicos venían a solucionar el problema del hambre en el mundo. Actualmente, no sólo se reconoce la falacia de ese argumento por cuanto la problemática alimentaria sigue incrementándose y complejizándose (incluyendo la dicotomía de obesidad y hambre), al tiempo que se ha comprobado que no es necesario una mayor producción sino la mejora de los sistemas de acceso y distribución (Patel, 2008).

\section{Análisis del PEA 2020}

El Plan se aboca a definir un modelo que permita

profundizar la tendencia ya iniciada años pasados en la generación de valor agregado, con fuerte inserción de la Argentina en las cadenas globales de valor mundiales y, al mismo tiempo, promover que tal generación de valor se desarrolle no sólo globalmente sino fundamentalmente en origen, a fin de impulsar un proceso de desarrollo con equidad, todo ello en un marco de sustentabilidad ambiental y territorial (MAGyP, 2011, p. 80).

De esta definición rescatamos tres elementos, que están presentes en todo el Plan y se constituyen como sus pilares, a saber: (1) la decisión de continuar y fortalecer el proceso de agroindustrialización, (2) el objetivo de "agregado de valor en origen” que apuntaría a revertir el desarrollo geográfico desigual y (3) la búsqueda de sustentabilidad en el plano ambiental, social y económico. Sobre la base de estos postulados se construye lo que fue definido como Modelo de Valor Agregado con Desarrollo, a través del cual se contribuirá al “desarrollo de la Nación y sus Regiones” (MAGyP, 2011). Los elementos componentes de este último son: la equidad territorial (que involucra el arraigo, la ocupación del territorio, y desarrollo regional), la inclusión social (que requiere de seguridad alimentaria nutricional, empleo y seguridad social) y la Sustentabilidad Ambiental (MAGyP, 2011, p. 84).

El ethos neodesarrollista del PEA 2020 se hace visible cuando concibe a la agroindustrialización (especialmente en origen y de la mano de empresarios "nacionales”) y al vínculo con mercados competitivos globales como medios para lograr el "desarrollo" (tal como se sintetizó antes: desarrollo desde dentro, hacia el exterior). La estrategia de desarrollo del PEA 2020 se funda en la generación de entramados productivos en torno de agroindustrias competitivas internacionalmente, aunque más adelante reconoce la posibilidad de que “el valor agregado no sólo sea en bienes, sino también en servicios exportables” (MAGyP, 2011, p. 72). 
En el Capítulo 2 se realiza una caracterización de la evolución del sector agroalimentario y agroindustrial argentino y se asumen dos modalidades de organización productivas como predominantes en el agro del siglo XXI, que se denomina "modelo de la nueva agricultura argentina" (MAGyP, 2011, p. 44), a saber: por un lado la compleja red de agentes vinculados por una multiplicidad de contratos, asociada al management empresarial y al uso de las nuevas tecnologías, y por otro lado un sector caracterizado por la tradicional integración vertical de actividades donde el productor (“familiar” principalmente) continua siendo el epicentro de la toma de decisiones, generando valor agregado en origen. El documento establece que "generará condiciones a fin de que estas dos modalidades puedan convivir en un futuro cercano" (MAGyP, 2011, p. 43). Esa afirmación deja entrever el supuesto de la coexistencia entre el sector del agronegocio y el de los pequeños y medianos productores, sobre la base de la sumisión a una agricultura capitalista. Por tanto, el ethos neodesarrollista del PEA 2020 se manifiesta en los supuestos que fundamentan su estrategia de desarrollo: la (agro)industrialización (especialmente si se logra la integración en cadenas, con agregado de valor en origen e inserción externa) propenderá dinamismo económico y, consecuentemente, la generación de empleo. Así, el Plan pugna por "un proceso de reconfiguración del sistema productivo que permita (...) desarrollar una agroindustria que a su vez tenga los medios para generar empleo para muchos, en contextos territoriales que posibiliten una nueva ruralidad” (MAGyP, 2011, p. 45, cursivas propias). La cita da cuenta de que en el esquema del Plan el eje del desarrollo pasa por la profundización de la agroindustrialización en el marco de una estrategia, cuyo fin último se resume en la expresión: «Argentina: líder agroalimentario» (lema del PEA 2020). Asimismo, en este planteo es la (gran) agroindustria (con inserción internacional) la que absorbería la mano de obra que rechaza el campo. De allí la necesidad de incorporar, para el logro de las metas de sustentabilidad social el enfoque de la "Nueva Ruralidad" cuyas implicancias observaremos luego. Por último, este postulado puede ser señalado además como la persistencia de un esquema en el que las necesidades agroalimentarias continúan subsumidas a los imperativos de la industria (y del mercado global).

Por otra parte, el espíritu neodesarrollista del PEA 2020 puede reconocerse también cuando promueve un rol activo del Estado en la redistribución de los beneficios obtenidos del comercio exterior. Así, el Plan "se replantea el sentido y la instrumentación de futuras estrategias de inserción externas, en pos de captar mayores rentas internacionales y aplicarlas al proceso de desarrollo interno, promoviendo el Estado Nacional políticas de desarrollo territorial” (MAGyP, 2011, p. 45). Tal como se afirmó antes, el Plan recupera el protagonismo estatal: a fin de promover un desarrollo desde dentro reivindica un activo accionar en el comercio exterior, cuyo correlato hacia el interior se enmarca en lo que ha sido enunciado como enfoque territorial del desarrollo. En este marco, el PEA 2020 ubica el logro de las metas sociales y ambientales en el "paraguas" que le ofrece la noción de "Nueva Ruralidad” (NR), que debe ser promovida en los años venideros.

Según el Plan la NR permitirá

equilibrar el modelo de la agricultura industrializada de gran escala que se asienta en la concentración del capital a nivel global, y que habrá de consolidar a la Argentina como líder mundial agroalimentario y agroindustrial, con los objetivos estratégicos socioculturales y ambientales (MAGyP, 2011, p. 45, cursivas propias).

Tal como se la concibe, la NR es un elemento clave en el logro de las metas socioculturales y ambientales y es en este marco que se intentará comprenderla. En el momento de figurar qué se entiende por ella, se describe la siguiente imagen:

un interior rural con más pueblos y pequeñas ciudades integrados a la economía nacional, que revalorice el lugar de la juventud trabajadora, la convoque y la integre a la producción y al crecimiento, con mejora en las condiciones de vida que implica trabajo en el lugar, educación, salud, 
alimentación, vivienda, caminos e infraestructura (ibid.).

Así entendida, la NR abarca un sinnúmero de situaciones espaciales y de actividades económicas, lo cual ha sido enunciado como una mirada que enfatiza en la "multifuncionalidad" de los espacios rurales (Bonnal et al., 2003), en un esquema en el que la producción agraria es sólo un elemento entre una amplia gama de aspectos a considerar. Por ejemplo, los elementos centrales de la NR del PEA 2020 son las mejoras en las condiciones de vida y el énfasis en los jóvenes como protagonistas (dos elementos centrales del discurso neodesarrollista). La contraparte de esta forma de comprender la ruralidad es que queda vaciada de una referencia al trabajo agropecuario, a la generación de alimentos y al vínculo con la tierra, lo cual es especialmente importante en el momento de definir una política pública. En este punto, cobra importancia la advertencia señalada por Teubal (2001, p. 61), en el sentido de que "es muy probable que tal ruralidad resulte vaciada en forma creciente de su contenido agrario", que pareciera ser pertinente en el caso del PEA 2020. También está presente en los postulados del PEA 2020 la asociación entre la nueva ruralidad y la competitividad de algunos sectores, señalándose como indicadores de la misma el crecimiento en el uso de la biotecnología y de fertilizantes (por cuanto se infiere su vinculación con la imagen de "productor del siglo XXI”). $\underline{19}$

El documento fundamenta su plan de desarrollo, definido como "Modelo de Valor Agregado con Desarrollo", en un análisis de la evolución del mercado global, aunque sin descuidar el mercado interno (cuyo abastecimiento queda vinculado a las metas "socioculturales"). Por tanto, en este punto también se hace visible otro de los rasgos característicos de la lógica del agronegocio, esto es: la consideración estratégica y prioritaria de las necesidades del consumidor global (Gras y Hernández, 2013, p. 26). Con esta perspectiva en su Capítulo Cuarto describe y analiza el contexto global, abonando la conclusión de que la coyuntura externa es favorable para un país que se perfile como productor de alimentos (debido a las tendencias de urbanización y de los cambios en las pautas de consumo en los países emergentes). Asimismo, para ampliar las producciones recomienda aumentar los rendimientos a causa de la producción de agrocombustibles y por la escasez de agua y de tierra. Así, concluye que el "desafío de este período, y que deberá plasmarse en el PEA, será cómo aprovechar adecuadamente las oportunidades de un mundo emergente en rápido crecimiento, balanceando debidamente el mejor rédito a obtener del agro" (MAGyP, 2011, p. 72). En este sentido, el PEA proyecta una estrategia para el agro en sintonía con una inserción internacional en el marco del "Consenso de los Commodities” señalado por Svampa (2012), reforzando la imagen de un "país góndola” (Katz, 2013).

En función del "Modelo" que promueve el Plan se establecen "metas" que con mayor profundidad permiten observar, desentrañar y puntualizar los elementos componentes, e implicancias, de esta propuesta neodesarrollista para el agro. En su Capítulo Quinto establece cuatro "fines estratégicos": el EconómicoProductivo, el Socio-Cultural, el Ambiental-Territorial y el Institucional. Como fin económico-productivo el PEA busca "impulsar la generación de riqueza económica con mayor valor agregado, en particular en origen, en un contexto de competitividad sistémica, con crecimiento sustentable en el tiempo, equitativo desde lo social y sostenible desde lo ambiental”. En primer lugar, proyecta que esta meta se alcanzará a través de un "mayor volumen y diversidad” de producción agroalimentaria y agroindustrial; lo que será logrado a través de: (a) un crecimiento de la superficie implantada (con granos en un $27 \%$ más, con cultivos industriales en un 9\%, un $126 \%$ más de algodón, un $4 \%$ más de horticultura, un $25 \%$ más del complejo forestal, un 15\% de cultivos vitivinícolas y un $9 \%$ más de superficie con frutas); de (b) un aumento en el stock de carnes (bovinas un 10\% más, porcinas un 57\% más y ovinas un 7\% más), del complejo lácteobovino (un 37\% más de cabezas) y de las capturas marítimas (en un 24\%); y (c) de un crecimiento de la productividad agropecuaria vía intensificación productiva (Objetivo específico Nro. 2). -Así, la mayor superficie implantada y mayor productividad agropecuaria permitirá una mayor producción agroalimentaria 
y agroindustrial en Argentina. Con este fin el PEA 2020 considera necesario "estimular el desarrollo, la difusión y la adopción de innovaciones tecnológicas” (Objetivo específico Nro. 4) y, al mismo tiempo, "fomentar el desarrollo de formas organizativas" (Objetivo específico Nro. 5 y 6). Además, se contempla el diseño y la ejecución de las "obras de infraestructura pública requeridas para el pleno desarrollo económico y social derivado de las actividades agroalimentarias y agroindustriales” (Objetivo específico Nro.7).

Consecuentemente con el programa neodesarrollista, este crecimiento de la producción se hace con miras a “aumentar el volumen de las exportaciones agroalimentarias y agroindustriales argentinas con énfasis en las producciones con mayor valor agregado”, aspirando a un 153\% de crecimiento (Objetivo específico Nro. 3). Particularmente, se anhela un aumento del $80 \%$ en las exportaciones primarias, del $193 \%$ en las MOA (Manufacturas de Origen Agropecuario) y 317\% de las exportaciones de biocombustibles derivados de la soja (no se contempla la exportación de otros bio/agrocombustibles), manifestándose así el rol estratégico de estos combustibles para el proyecto socioeconómico del gobierno.

\section{La perspectiva de sustentabilidad del PEA}

En primer lugar, es preciso afirmar que el PEA 2020 constituye un sólido avance en la incorporación de criterios explícitos de "sustentabilidad" para la actividad agrícola. Así, el PEA 2020 se propone como Fin estratégico ambiental-territorial "estimular el desarrollo productivo resguardando el equilibrio entre la competitividad sectorial y la sostenibilidad ambiental social y económica de cada territorio” (MAGyP, 2011, p. 130). Al respecto, vale afirmar que la perspectiva del desarrollo sostenible presupone la búsqueda de un conjunto de sustentabilidades, que pueden ser sintetizadas en el logro de una eficiencia económica y eficacia social con cuidado ambiental. Sin embargo, los diversos entendimientos en la materia plantean la necesidad de discernir el enfoque de sustentabilidad subyacente a cada discurso. Con este fin retomamos los estudios de Foladori y Tommasino (2000), para quienes la discusión sobre el desarrollo sustentable contuvo desde su origen dos tipos de preocupaciones: una estrictamente ecológica ligada a la depredación de recursos, al aumento de la contaminación y a la pérdida de valores “ecológicos” (como la biodiversidad, los paisajes y el medio ambiente de vida en general), y otra más bien social (referida a cómo la pobreza genera y es resultado del deterioro ambiental); al tiempo que la dimensión "económica” subyace en la idea de "desarrollo". A partir de este planteo, los autores organizan la variedad de posiciones sobre «la sustentabilidad» como un continuum, agrupándolas en torno a tres grandes ejes, según prioricen una u otra de estas dimensiones: (a) aquellos para quienes la "sustentabilidad es exclusivamente ecológica"; (b) aquellos para quienes la sustentabilidad social interesa en la medida en que constituye un elemento que afecta a la sustentabilidad ecológica, es decir, una "sustentabilidad social limitada". Y finalmente, (c) quienes consideran que la sustentabilidad debe atender a una “coevolución Sociedad-Naturaleza”. En el mismo sentido Gudynas (2003) ha generado tres categorías de sustentabilidad: débil, fuerte y superfuerte. $\underline{20}$

En relación al fundamento de estos diferentes entendimientos de la sustentabilidad, varios autores coinciden en señalar la existencia de al menos tres corrientes dentro del ambientalismo (Pierri, 2001; Martínez Alier, 2004; Foladori y Tommasino, 2000; Foladori, 2001). Por un lado se ha reconocido la «ecologistaconservacionista», por otro el «ambientalismo moderado», y finalmente una visión que hemos denominado «crítica». ${ }^{21}$ Por su parte, otra posición sería la de los “cornucopianos” o "tecnocentristas de mercado”, que sin embargo "está fuera de la discusión sobre sustentabilidad" dado que por su optimismo técnico consideran que los problemas ambientales, si existieran, serían resueltos “naturalmente” (Foladori y Tommasino, 2000, p. 49).

En principio, el PEA 2020 postula la “compatibilidad" entre las metas económico-mercantiles, socioculturales y ambientales (bajo el paraguas de la noción de nueva ruralidad). Sin embargo, la 
subordinación de los objetivos socioculturales y ambientales, puede percibirse cuando plantea que si bien se deberán "tener en cuenta los factores económicos, regionales, ambientales y de empleo", la "asignatura pendiente es lograr un mayor agregado de valor a la producción primaria y de primera industrialización” (MAGyP, 2011, p. 72). Así, la cita referida da cuenta de que los “pendientes” para el PEA 2020, y por tanto las prioridades que establece, se orientan a profundizar la agroindustrialización. Entonces, se identifica que las metas de sustentabilidad socioambiental del Plan se encuentran subordinadas a las de productividadrentabilidad económica. Por ello algunos autores han señalado que en el caso del PEA

una retórica a favor de la sustentabilidad aparece junto a medidas fuertemente 'productivistas' y 'desarrollistas', acordes a la filosofía del progreso material que instituyó la modernidad (y sin considerar elementos que inciden fuertemente en el ambiente como la organización territorial, el uso del suelo o la distribución de la población) (Silvetti et al., 2013: s/n).

El PEA se propone como Fin estratégico ambiental-territorial "estimular el desarrollo productivo resguardando el equilibrio entre la competitividad sectorial y la sostenibilidad ambiental social y económica de cada territorio” (MAGyP, 2011, p. 130). Se resalta que es sobre la base de un interés humano que el PEA establece criterios para la relación entre la sociedad y el ambiente. Así, la meta ambiental-territorial propuesta parte de la disposición a continuar y profundizar las actividades económicas existentes, sustentándose por ende en una perspectiva ética antropocéntrica. En este marco se promueven políticas de dos tipos: de comando y control, orientadas a regular el uso de los recursos o la generación de desechos, y las basadas en instrumentos de mercado que buscan internalizar externalidades. Por ejemplo, el tercer objetivo específico se orienta a "impulsar la puesta en valor ambiental de los bienes del sector”, lo que implicaría que para el año 2020 "el 2\% de las tierras de alto valor ecológico de Argentina sean valoradas mediante mecanismos económicos y financieros que impliquen un reconocimiento a los servicios eco-sistémicos esenciales que proveen a la sociedad". En todo caso, las soluciones propuestas buscan al mismo tiempo la "ganancia económica y ganancia ecológica”, en los términos de Martínez Alier (2004, p. 22), bajo una perspectiva que interpreta al desarrollo sostenible como "crecimiento económico sostenible".

Asimismo, se destaca que en muchos casos predomina una visión fragmentaria de la naturaleza, por cuanto se establecen "soluciones" para una problemática sin considerar la influencia sistémica de la misma. Un ejemplo de ello es el caso del Objetivo específico 2, que se orienta en particular a "asegurar la sustentabilidad ambiental”, y en su punto (b) establece como meta para su logro el incremento de la superficie de forestal igualando los cultivos de árboles a los bosques nativos, y que puede vincularse a la meta (a), que intenta recuperar el carbono a través de la forestación. Sin embargo, quedan ausentes de este planteo los impactos derivados de los cultivos forestales, que muchas organizaciones ecologistas reúsan en llamar bosques (debido a la reducción en términos de biodiversidad que todo monocultivo supone). Finalmente, en el caso (c) (ver nota al pie 51), se establecen metas preservacionistas, lo que puede ser interpretado en el sentido de la posible confluencia entre las corrientes ligadas al ecoeficientismo y los conservacionistas (ver al respecto razonamiento en Pierri, 2001).

En síntesis, la perspectiva de sustentabilidad que mantiene el PEA puede traducirse en una apuesta por medidas que (a) se sustentan en una visión fragmentaria de los componentes del ambiente, (b) confían en la capacidad de manipular y ejercer control sobre el ambiente mediante el progreso técnico y en la expansión de la valorización económica de bienes y servicios ambientales como medios para lograr la sustentabilidad ambiental, (c) profundizan la mercantilización de la Naturaleza. Entonces, y usando como base la tipología del ambientalismo antes presentada, afirmamos que la propuesta del PEA se corresponde con una perspectiva ecoeficientista y de ambientalismo moderado, en tanto este enfoque considera que el objetivo de las políticas ambientales es realizar "correcciones técnicas en el proceso productivo" a fin de alcanzar niveles razonables u óptimos de funcionamiento (Foladori, 2001, p. 101). Ello conlleva la creencia de que los problemas entre el 
desarrollo capitalista y el ambiente pueden ser resueltos a través de políticas específicas. Por lo demás, las propuestas ambientales del PEA proponen una ampliación de los límites del mercado y podrían ser enmarcadas en lo que tanto Gudynas (2003) como Foladori y Tomassino (2000) consideran como “sustentabilidad débil”, por cuanto plantean la discusión sobre qué partes y cuánto conservar, confluyendo en propuestas políticas preservacionistas y en la búsqueda de soluciones técnicas.

En última instancia el PEA da cuenta de la confianza del neodesarrollismo en la capacidad del capitalismo de resolver los problemas ambientales que él mismo genera. Sin embargo, resulta probable que un renovado avance del agronegocio y de la expansión de la frontera agropecuaria (derivados de la consumación de los objetivos económico-productivos del Plan) suponga el reforzamiento de los sesgos extractivos del modelo de agricultura industrial, expresados en el deterioro biológico y cultural de los territorios rurales del país y en la expulsión de las comunidades que allí viven. Todo lo cual significaría una fuerte profundización de las tendencias vigentes hacia la concentración económica y territorial (con los evidentes perjuicios socioambientales asociados), socavando la posibilidad de alcanzar las metas de sustentabilidad ambiental y sociocultural. De este modo el PEA 2020 permite percibir cómo el "ambientalismo moderado" (Foladori, 2001), es coherente con un patrón de acumulación que perpetúa el despojo (Harvey, 2004).

\section{Consideraciones finales}

El análisis de los elementos del PEA 2020 y de las principales políticas hacia el agro permite inferir que un plan neodesarrollista para el mundo rural asume al empresariado (nacional y trasnacional) como actor dinámico; plantea como objetivo principal el aumento de la producción (especialmente las de mayor valor agregado y con fuerte integración en cadenas globales y locales de valor) a la par que incentiva la inserción en mercados externos; concibe a la agroindustrialización y al agregado de valor en origen como mecanismos para el desarrollo territorial; promueve la generación de entramados en torno de agroindustrias con competitividad internacional y alienta un rol activo del Estado en la planificación y la redistribución de los beneficios. De ello se infiere la persistencia de una mirada del agro como negocio, pese a la perspectiva que pretende con metas de sustentabilidad social y ambiental disimular objetivos mercantiles y productivistas. Por tanto, se concluye que el PEA 2020 representa una fuerte apuesta a la intensificación y expansión del agronegocio, en tanto alienta un modelo de producción agropecuaria marcado por la ampliación de la escala y la “managerialización”.

Por su parte, las últimas políticas del kirchnerismo hacía el agro (especialmente la pretensión de modificar la ley de semillas y la expansión de la biotecnología) permiten vislumbrar que, si bien la Ley de Agricultura Familiar significó un hito en el sentido de proteger al sector productor más vulnerable del mundo rural, no implica en sí misma una reversión de la tendencia de primacía de la lógica del agronegocio, y en algún sentido resulta complementaria de ésta. Al respecto de la posibilidad de esta "coexistencia”, Giarraca y Langlais (2015, p. 55) han señalado

la historia está plagada de ejemplos que muestran la imposibilidad de estos encuentros pacificadores cuando lo que está en juego es la tierra y su 'limitud', las ganancias y abultadas rentas. Por las razones expresadas, si la ley se implementa los conflictos se acentuarían. El cercenar el 'uso propio', dará lugar a una violencia (ej. casos de decomiso) aún mayor hacia el campesinado.

Lo antedicho abona la afirmación de que no hubo en la última década una transformación de las tendencias estructurales visualizadas en el período neoliberal para el mundo rural, pese a la mayor presencia estatal en el sector. Al contrario, y pese a los instrumentos generados que buscan regular y amortiguar los efectos sociales y ambientales más brutales del extractivismo inherente a la lógica del agronegocio, el neodesarrollismo en general, y el PEA 2020 en particular, contribuyen a profundizar la lógica que impera en los espacios rurales 
argentinos desde los noventa.

\section{Notas}

1 La utilización de este concepto permite concebir las tendencias actuales a la luz de la historia común del subcontinente, así como dar cuenta de las especificidades de la etapa actual. En los términos de Seoane (2012, p. 3), habilita una "delimitación del pasado y del presente del modelo extractivo exportador". Así, este autor plantea la existencia de "una memoria larga" o un "ciclo largo" del extractivismo latinoamericano, que se remonta a la conquista y colonización de los espacios geográficos que hoy denominamos África y América. Luego, una memoria más reciente que se conforma a partir de las independencias latinoamericanas, a lo largo del siglo XIX y se prolonga a comienzos del XX. Por último, la etapa actual integraría el "ciclo corto del extractivismo” iniciado en los setenta con el régimen de acumulación flexible y la valorización financiera que en Latinoamérica implicó la reprimarización y, en cuanto a la inserción internacional, la especialización en commodities o bienes recurso-naturales intensivos, siendo la flexibilización ambiental y laboral los ejes de la reconfiguración de la dinámica socioeconómica del nuevo modelo (Seoane, 2012). Por su parte, el colapso del neoliberalismo significará una reformulación del extractivismo, generando algunos matices en relación al período previo. Según Gudynas (2011) el (neo)extractivismo actual se distingue del convencional, y especialmente de aquel de las décadas de 1980 y 1990, por tener una mayor presencia estatal, con reglas más claras, de sesgo progresista, y con un discurso que apunta a la «globalización» y la «competitividad». La constatación de este proceso permite afirmar la existencia de un "neoextractivismo progresista” (Gudynas, 2011, p. 79).

$\underline{2}$ La función del tipo de cambio en el neoestructuralismo sería "asegurar la viabilidad competitiva de las industrias de intercambio que emplean tecnología de avanzada” (Féliz, 2012, p. 18). En este esquema, un dólar caro y una tasa de interés moderada son más importantes que una activa política de promoción industrial (aunque esto no implica la inexistencia de tales).

3̧Según Féliz y López (2012, p. 70), “el objetivo de la contención de los salarios es satisfacer la necesidad de ahorro interno suficiente para sostener la acumulación de capital”. Así, se intenta contener las demandas salariales dentro de los parámetros establecidos por la evolución de la inflación y la productividad del trabajo, dado que "el aumento de los salarios por encima de la productividad se traduce inmediatamente en un aumento de los costos unitarios de producción y, consecuentemente, en una reducción de la rentabilidad” (Féliz y López, 2012, p. 69). Asimismo, si no se contienen los salarios y las empresas "trasladan” los mayores costos salariales a sus precios perderán ventaja competitiva frente a productores de otros países.

4 Siguiendo a Sztulwark, Féliz (2012, p. 17) afirma que "el neoestructuralismo atravesó una fuerte revisión crítica en un camino de convergencia con el neoliberalismo", traspasando el foco de interés, en tanto base del desarrollo, "de la industrialización a la estabilidad macroeconómica”, y "de la superación de la condición periférica y el subdesarrollo a la transformación productiva con equidad”. En el viejo estructuralismo las políticas industriales incluían subsidios y promoción para favorecer a los sectores señalados como estratégicos, mientras que las empresas estatales cumplían un rol fundamental como proveedoras de insumos a precios subsidiados (FélizyLópez, 2012, p. 68).

5 Monsanto Argentina S.A. (filial) no logró patentar el gen RR en el país, por tanto, las empresas comercializadoras no cobraron los derechos de propiedad intelectual y los productores pudieron continuar con la práctica tradicional de guardar semillas de una temporada a la otra (lo cual facilitó la difusión de la semilla transgénica por circuitos informales (práctica conocida como de la "bolsa blanca"). Al mismo tiempo, el precio del glifosato se mantuvo muy bajo en nuestro país mientras que la menor mano de obra necesaria por la utilización de la siembra directa contribuía a disminuir los costos asociados al laboreo de los 
productores que pudieron volcarse al nuevo modelo (Domínguez \& Sabatino, 2006).

6 Otra víctima por defender su territorio (18 de noviembre de 2011), Página12, recuperado de http://www.pagina12.com.ar/diario/sociedad/3-181517-2011-11-18.html. Ello reforzó la demanda de medidas de control de los arrendamientos, freno a los desalojos y de preservación de los bienes naturales, etc., realizadas por algunas organizaciones representativas de medianos y pequeños productores, sin las cuales estimaban que difícilmente se revertirían los impactos negativos del sistema agroalimentario argentino. El reclamo se venía realizando desde el FONAF, en donde se proponía una profunda reforma legislativa (que incorporaba también una ley de extranjerización) (FONAF, 2006, p. 13). Así cobró forma una propuesta de "Ley de freno a los desalojos", que a partir del 2011 pasó a ser conocida como "Ley Cristian Ferreyra”. La Ley № 27.118 “de reparación histórica de la agricultura familiar para la construcción de una nueva ruralidad en la Argentina”, incorpora algunos puntos.

$\underline{7}$ A principios del nuevo siglo nacía la organización "Madres de Ituzaingó” (en barrio Ituzaingó Anexo, en las afueras de Córdoba) ante la preocupación por la gran cantidad de enfermos de cáncer y niños con malformaciones. A medida que las enfermedades se multiplicaban las madres relevaron los casos y denunciaron a sojeros y a la dirigencia política, por complicidad. Las fumigaciones con agrotóxicos llegaban hasta las puertas de las viviendas (Aranda D., 2009). En este marco en 2006 se lanzó la campaña «Paren de Fumigar» con el objetivo de identificar poblaciones afectadas por el uso de agrotóxicos, que derivó en la publicación de un Primer Informe sobre Pueblos Fumigados (GRR, 2006). Sobre esta base se demandaban, en los términos del informe, "políticas de Estado que fijen pautas racionales para el uso de los agrotóxicos (...). Esas políticas deberían establecer zonas de producción de alimentos para las poblaciones locales en desmedro de la agricultura industrial, zonas que hagan a la vez de contención y preservación de las poblaciones, políticas sanitarias que eviten que continúe la contaminación de las cuencas hídricas y que preserven las fuentes de agua potable de los pueblos, políticas que fijen extremas medidas de control tanto para fumigadores como para cerealeras, transportes incluidos, y que por sobre todo prioricen la vida de la gente por encima de todo lucro empresarial” (GRR, 2006, p. 33).

$\underline{8}$ En junio de 2010 el Municipio de Cañuelas sancionó una de las ordenanzas más restrictivas, prohibiendo las fumigaciones con herbicidas aéreos en todo el territorio de Cañuelas y las terrestres en un radio de 2.000 metros alrededor de zonas urbanas, residenciales o de quintas y cursos de agua. En otros municipios se replicó el ejemplo con zonas de menor tamaño. Asimismo, esa creciente proliferación de ordenanzas ha sido interpretado como parte de la perspectiva gubernamental que sustenta la coexistencia del agronegocio con la agricultura pequeña y familiar. Así, algunas organizaciones (entre las cuales destacamos al GRR, por haber sido una de las primeras promotoras de estas legislaciones, a partir de la campaña «Paren de Fumigar») como una forma indirecta de habilitar el saqueo en el mundo rural. Ello queda expresado en el "Informe Final de la Campaña Paren de Fumigar”, realizado por el GRR donde se afirma "la incorporación reciente de Diputados Nacionales del oficialismo a la Campaña contra las fumigaciones, basándose en denunciar el glifosato, además de centralizar la atención en apenas un aspecto del problema, tiende a extraviar las protestas en inconducentes y exclusivos caminos jurídicos (...), desviar las energías de la protesta y convertirlas paulatinamente en campañas inocuas que, en vez de impugnar al modelo, terminen legitimándolo y haciéndolo aceptable. De esa manera, (...) pretenden reducir la lucha de los pueblos fumigados a denunciar el Glifosato o a discutir tan solo la cantidad de metros que distarían los primeros campos de soja de la última calle de los pueblos" (GRR, 2010). De este modo se pasaba del lema "Paren de fumigar" al "Paren de fumigarnos”, aglutinando a un nuevo arco de organizaciones sociales en pos de una crítica integral al modelo del agronegocio.

$\underline{9}$ Se destacan las controversias en torno a las investigaciones del Dr. Carrasco sobre los efectos del glifosato en las cadenas tróficas que corroboraron el surgimiento de malformaciones en vertebrados. Véase Acosta H. 
et al. (2010).Para un resumen de este caso se recomienda el artículo de Carrasco (10 de abril de 2010).

10 En esta etapa se incrementan las represiones a las asambleas cordilleranas contra la minería, siendo los casos más paradigmáticos los de Famatina, Andalgalá y Tinogasta (en La Rioja y Catamarca). Además, la presión extractivista sobre los territorios derivó en un incremento de los conflictos por el respeto a los derechos ancestrales de las comunidades originarias (en particular en las provincias de Formosa y Neuquén). Paralelamente, en octubre de 2012 la presión del agronegocio se cobraba la vida de otro campesino (MoCaSE-VC, 14 de octubre de 2012).

11 Así, los autores distinguen dos elementos que ilustran este punto: (1) el carácter indirecto de la retención (por que la pagan las exportadoras al Estado pero éstas las trasladan a los productores), lo cual "puede dar lugar a numerosas irregularidades en el pago, simplemente por el modo en que es calculado el importe que debe ser abonado", de las que se beneficien estas intermediarias y (2) es preciso considerar que "si como ocurre en la actualidad y acorde a políticas neoliberales de larga data, prevalecen impuestos indirectos (...) el sistema impositivo tiende a ser regresivo" (TeubalyPalmisano, 2010, cursivas propias).

12 El Estatuto del Peón Rural aprobado fija una jornada laboral máxima de 8 horas diarias y 44 semanales y crea el RENATEA. Establece el descanso semanal con sábado inglés, licencia por paternidad de 30 días, baja la edad jubilatoria de los 65 años o 60 años en caso de las mujeres, a 57 años con 25 años de servicio y es taxativo en cuanto a que la remuneración del trabajador nunca podrá ser inferior al salario mínimo, vital y móvil. A su vez, tipifica distintas modalidades de contratación de trabajo agrario, como el trabajo permanente discontinuo (trabajador golondrina), que es la forma de ocupación de los dos tercios de los trabajadores agrarios. Estipula, además, el reconocimiento de horas extras, el descanso semanal, las condiciones adecuadas de higiene y seguridad, la provisión de ropa de trabajo por parte del empleador, el otorgamiento de licencias de la ley de Contrato de Trabajo, prohíbe el trabajo infantil y regula la contratación de menores de entre 16 y 18 años de edad. Finalmente, la norma prohíbe el pago salarial en moneda distinta a la de curso legal, sea en bonos o en especie.

$\underline{13}$ El "Régimen de Protección al Dominio Nacional sobre la Propiedad, posesión o Tenencia de las Tierras Rurales”, sancionado en diciembre de 2011, establece en un quince por ciento (15\%) el límite a la titularidad de dominio o posesión de tierras rurales por parte de extranjeros en el territorio nacional (con un porcentual equivalente en relación al territorio de la provincia, municipio, o entidad administrativa) (Art. 8), y que las tierras rurales de un mismo titular extranjero no podrán superar las mil hectáreas (1.000 ha) en la zona núcleo, o superficie equivalente, según la ubicación territorial (Art. 10). Estableciendo que la norma no es retroactiva. Además, en el Capítulo IV fija la creación de un Registro Nacional de Tierras Rurales. La Ley fue reglamentada través del Decreto 274/2012, en febrero de 2012. Pese al gran impacto que tuvo en términos mediáticos, desde diversos sectores se puso en duda la influencia real de esta medida en los fenómenos relativos a la concentración territorial y creciente extranjerización visualizada en el agro, así como se sostuvo la imperiosa necesidad de avanzar en otras medidas (de control de los arrendamientos, freno a los desalojos y de preservación de los bienes naturales) sin los cuales difícilmente se reviertan los impactos negativos en el agro (Ley $\mathrm{N}^{\circ}$ 26.737).

14 Por ejemplo, el Movimiento Nacional Campesino Indígena (MNCI) reconoció el carácter táctico de la propuesta, aunque remarcaron la ausencia de las principales demandas campesinas. Por su parte, la Federación Agraria Argentina (FAA) destacó que la norma exige ordenar un catastro y Pedro Peretti, su representante, señaló: "El Congreso Nacional debe aprobar leyes que limiten la extranjerización y regulen las condiciones de arrendamientos para revertir el avance de los pooles de siembra y para que podamos recuperar la chacra mixta. También es necesario avanzar en la suspensión de los desalojos rurales para regularizar el dominio de los campesinos poseedores sin título, a los que el Estado no les ha dado la posibilidad de obtenerlo, a pesar de ser quienes históricamente ocuparon esas tierras” (CTA, 2011). 
Finalmente, algunas organizaciones no gubernamentales denunciaron que el proyecto podría avalar la continuidad de las ventas a extranjeros registradas en los últimos años por cuanto en 2011 se estimaba en un $10 \%$ la superficie con propietarios foráneos, considerando asimismo absurdo o contradictorio "que los extranjeros no puedan tener la propiedad de las tierras, pero sí permitirles el uso, explotación y control de ellas” (GRR, 2011), relativizando así la importancia de la nueva normativa en términos del establecimiento de límites a la lógica del agronegocio.

15 Respetar la propiedad intelectual (22 de agosto de 2012) Pagina12, p. 7. Para más información sobre el conflicto por la ley de semillas se recomienda Peremulter, 2012. El proyecto oficial no logró salir de la Comisión Nacional de Semillas.

16 La Presidenta anunció la autorización de dos eventos biotecnológicos para la producción de soja y de papa (5 de octubre de 2015) Télam. Recuperado de http://www.telam.com.ar/notas/201510/122490-cristinabiotecnologia-produccion-soja-papa.html

17 Biotecnología argentina: soja contra sequía y papas sin virus (10 de octubre de 2015) La Nación. Recuperado de http://www.lanacion.com.ar/1835008-biotecnologia-argentina-soja-contra-sequia-y-papassin-virus

18 La Presidenta... (5 de octubre de 2015)Télam.

19 “Entre 2005 y 2009, se inscribió en el INASE entre el 25\% y el 35\% de toda la genética existente para los cultivos de soja, trigo, maíz, sorgo y girasol. Por otra parte, fue en el último quinquenio cuando se alcanzó el mayor consumo histórico de fertilizantes, lo cual es indicador de una agricultura que apunta a incrementar la productividad unitaria y la sustentabilidad por medio de la reposición de los nutrientes que extraen los cultivos. En ese lapso, se construyeron dos nuevas fábricas de fertilizantes fosforados que sustituyen importaciones, agregando valor en Argentina y generando empleo y oportunidades. (...) Estas particularidades que indican la presencia de una nueva ruralidad” (MAGyP, 2011, p. 65).

$\underline{20}$ La Sustentabilidad Débil “acepta la valoración económica como método de valoración primordial y por lo tanto es parte de una valoración antropocéntrica, donde la Naturaleza es objeto de valor de uso cambio, en función del ser humano” (Gudynas, 2003, p. 96). Esta idea iguala a la Naturaleza con otras formas de capital lográndose la sustentabilidad al mantener el Capital total constante. Por su parte, la Sustentabilidad Fuerte si bien acepta el concepto de "Capital Natural", se limita la sustitución con otras formas de capital dado que considera que una parte sustantiva del Capital Natural es un "acervo crítico" que debe ser protegido y que una vez convertido en otras formas de capital no es recuperable, "o al menos no lo es fácilmente” (Gudynas, 2003, p. 96). Además, permite otro tipo de valoración de la Naturaleza, más allá de la económica (sin rechazarla). Por su parte, el uso del concepto de Patrimonio Natural es la base de una Perspectiva Superfuerte del desarrollo sustentable, bajo la cual "la meta de conservación del ambiente es un fin en sí mismo que descansa en un imperativo ético” (Gudynas, 2003, p. 97). Es este sentido, implica un reconocimiento de valores intrínsecos y plantea la necesidad de preservar las singularidades de la Naturaleza por únicas e irremplazables, en función de asegurar la permanencia de los procesos evolutivos. Esto se opone totalmente con la idea de sustitución aunque sin renunciar al uso de los bienes naturales para satisfacer necesidades humanas, cuyo límite está dado por los mismos procesos evolutivos. De la misma forma, el concepto de Patrimonio incorpora una noción de responsabilidad sin necesidad de una propiedad, demandando una adecuada regulación ecológica y social de su manejo (Gudynas, 2003 pp. 98-99).

21 La corriente «ecologista-conservacionista» referencia una perspectiva ética fuertemente biocéntrica; su preocupación central es la preservación del mundo "natural" (entendiéndolo como aquello con la menor intervención humana posible). En este sentido, su preocupación es el logro de una sustentabilidad 
estrictamente ecológica. Postula un crecimiento económico y poblacional nulo (Pierri, 2001, p. 27; Martínez Alier, 2004, p. 22). La corriente del «ambientalismo moderado», también definida como "ecoeficientismo" (Martínez Alier 2004) o "tecnocentrista" (Foladori, 2001: 86), si bien reconoce la existencia de ciertos límites que impone la Naturaleza al crecimiento económico, confía que en última instancia el desarrollo científico-técnico proveerá de instrumentos para mejorar el funcionamiento del mercado, por lo cual se la ha caracterizado como desarrollista y antropocéntrica (Foladori y Tommasino, 2000, p. 49). Se expresa en la Declaración de Estocolmo y el Informe Brundtland (Pierri, 2001, pp. 27-28 y pp. 41-42). Así, podría ser enmarcada en lo que Gudynas (2003) denomina «sustentabilidad débil». La corriente «crítica» se caracteriza por considerar que para lograr la sustentabilidad es necesario un cambio social radical, dado que no puede ser lograda ni a través del mercado ni en el marco del modelo de acumulación vigente. Así, la crisis ambiental es inherente al modo de producción capitalista y sólo su superación permitirá resolverla (Pierri, 2001, p. 28).

\section{Bibliografía}

Acosta, H., Carrasco A., Paganelli A., López, S. \& V. Gnazzo (2010). Glyphosate-BasedHerbicides Produce Teratogenic Effects on Vertebrates by Impairing Retinoic Acid Signaling. ChemicalResearch in Toxicology. Recuperado de http://www.rapaluruguay.org/glifosato/Efectos\%20teratogenicos\%20del\%20Glifosato.pdf

Aranda, D. (12 de enero de 2009). El veneno que asoló el barrio de Ituzaingó. Pagina12. Recuperado de http://www.pagina12.com.ar/diario/elpais/1-118075-2009-01-12.html

Aranda, D. (09 de junio de 2015). Semillas, corporaciones y un proyecto cuestionado. $M u$. Recuperado de http://www.lavaca.org/notas/semillas-corporaciones-y-un-proyecto-cuestionado/

Arceo, N., González, M., Mendizabal y N. Basualdo E. (2010). La economía argentina de la posconvertibilidad en tiempos de crisis mundial. Buenos Aires: CIFRA-CTA.

Azpiazu, D. y M. Schorr (2010). La industria argentina en la posconvertibilidad: reactivación y legados del neoliberalismo. Problemas del Desarrollo. Revista Latinoamericana de Economía 161.

Balsa, J. (comp.). (2013). Discurso, política y acumulación en el Kirchnerismo. Buenos Aires: Centro Cultural de la Cooperación y Universidad Nacional de Quilmes-Bernal.

Barsky, O. (2013). Las políticas agrarias en tiempo de kirchnerismo. En Balsa, J. (comp.). Discurso, política y acumulación en el Kirchnerismo. Buenos Aires: Centro Cultural de la Cooperación y Universidad Nacional de Quilmes-Bernal. (pp. 341-367).

Bonnal, P., Bosc, P., Diaz, J. y B. Losch (2003). Multifuncionalidad de la agricultura y Nueva ruralidad. ¿Restructuración de las políticas públicas a la hora de la globalización?. En Pérez, E. y Farah, M. A. (Comp.), Desarrollo rural y nueva ruralidad en América Latina y la Unión Europea. Bogotá: Pontificia Universidad Javeriana.

Carrasco, A. (10 de abril de 2010). Fumiguen a la ciencia. Mu. La vaca. Recuperado de http://www.lavaca.org/notas/fumiguen-a-la-ciencia/

Carrasco, A. (03 de septiembre de 2012). Glufosinato, un nuevo veneno. Mu. Recuperado de http://lavaca.org/notas/glufosinato-un-nuevo-veneno/

CTA (1 de septiembre de 2011). Los campesinos piden por la ley de arrendamiento y el freno a los desalojos. Frente Transversal. Recuperado de http://www.frentetransversal.org.ar/spip.php?article8228 
Domínguez, D. y P. Sabatino (2006). Con la soja al cuello: crónica de un país hambriento productor de divisas. En Alimonda, H. (Comp.), Los tormentos de la materia. Aportes para una ecología política latinoamericana. Buenos Aires: CLACSO.

Féliz, M. y E. López (2012). Proyecto neodesarrollista en la Argentina ¿Modelo nacional popular o nueva etapa del desarrollo capitalista? Buenos Aires: Herramienta-El Colectivo.

Féliz, M. (2012). Proyecto sin clase: crítica al neoestructuralismo como fundamento del neodesarrollismo. En AAVV. Más allá del individuo.

Clases sociales, transformaciones económicas y políticas estatales en la Argentina contemporánea. Buenos Aires: Editorial El Colectivo.

Féliz, M. (2015). ¿ ¿Neodesarrollismo en retirada? Economía política de un proyecto de desarrollo. Argentina 2002-2015. Despierta 2 (2). Recuperado de http://redelp.net/revistas/index.php/rde/article/view/299

Foladori, G. (2001). Una tipología del pensamiento ambientalista. En Pierri, N. y G. Foladori (Ed.). ¿Sustentabilidad? Desacuerdos sobre el desarrollo sostenible. Montevideo: Trabajo y Capital.

Foladori, G. y H. Tommasino (2000). El concepto de desarrollo sustentable treinta años después. Desenvolvimento e Meio Ambiente 1, 41-56.

FONAF (2006). Documento final. Recuperado de: http://www.fonaf.org.ar/documentos/Documento Mendoza mayo 2006.pdf

Giarraca, N. y P. Langlais (2015). Algunas reflexiones sobre la coexistencia de sistemas agrarios ("agronegocio" y agricultura familiar) en la Ley de semilla. En AAVV: Regular el uso de las semillas entre biopoder, democracia alimentaria y mercados globales. Dossier para profundizar el debate(Junio). Buenos Aires: Consejo Consultivo de la Sociedad Civil-Cancillería Argentina.

Giarraca, N. y M. Teubal (Coord.) (2013). Actividades extractivas en expansión ¿Reprimarización de la economía argentina? Buenos Aires: Antropofagia.

Gras, C. y V. Hernández (2013) (Coord.). El agro como negocio. Producción, sociedad y territorios en la globalización. Buenos Aires: Biblos.

GRR (2006). Pueblos fumigados. Informe sobre la problemática del uso de plaguicidas en las principales provincias sojeras. Recuperado de http://www.grr.org.ar/trabajos/Plaguicidas\%20en\%20la\%20Argentina.pdf

GRR (6 de marzo de 2010). Informe Final de la Campaña Paren de Fumigar. Recuperado de http://www.grupodereflexionrural.com/documentos/informe\%20final\%20cpdf.htm

GRR (9 de septiembre de 2011) Proyecto de ley sobre extranjerización de tierras: Falsas soluciones y profundización del modelo. Recuperado de http://www.pararelmundo.com/documentos/proyectoextranjerizacion-tierras-falsas-soluciones-profundizacion-modelo/

Gudynas, E. (2011). El nuevo extractivismo progresista en América del Sur. Tesis sobre un viejo problema bajo nuevas expresiones. En AA.VV.: Colonialismos del siglo XXI. Negocios extractivos y defensa del territorio en América Latina. Barcelona: Icaria.

Gudynas, E. (2003). Ecología, economía y ética del desarrollo sostenible. La Paz: ICIB-ANCB.

Harvey, D. (2004). El “nuevo” imperialismo: acumulación por desposesión. SocialistRegister.

Katz, C. (2013). Las grietas del modelo. En Balsa, J. (Comp.). Discurso, política y acumulación en el Kirchnerismo. Buenos Aires: Centro Cultural de la Cooperación y Universidad Nacional de Quilmes-Bernal. 
Kornblihtt, J. Seiffer, T. y E. Mussi (2015). Las alternativas al Neoliberalismo como forma de reproducir la particularidad del capital en América del Sur. Pensamiento al margen 4. Recuperado de https://digitum.um.es/xmlui/bitstream/10201/51205/1/Las\%20alternativas\%20al\%20Neoliberalismo.pdf

MAGyP (19 de diciembre de 2014). Argentina tiene una Ley de Agricultura Familiar. Comunicado de Prensa. Recuperado de http://www.minagri.gob.ar/site/institucional/prensa/index.php? edit accion=noticia\&id info=141219120629\#

MAGyP (2011). Argentina Líder Agroalimentario. Plan Estratégico Agroalimentario y Agroindustrial Participativo y Federal 2010-2020, Metas 2020 para el Sector Agroalimentario y Agroindustrial argentino. Recuperado de http://inta.gob.ar/sites/default/files/inta 000001libro pea argentina lider agroalimentario.pdf

Martínez Alier, J. (2004). El ecologismo de los pobres. Conflictos ambientales y lenguajes de valoración. Barcelona: Icaria.

Martínez Dounac, G. (2013). Lógicas y tendencias de un modelo agrario que persiste. En Balsa J. (Comp.). Discurso, política y acumulación en el Kirchnerismo. Buenos Aires: Centro Cultural de la Cooperación y Universidad Nacional de Quilmes-Bernal. (pp. 325-340).

Mikkelsen, C. A. (2008). La expansión de la soja y su relación con la agricultura industrial. Revista Universitaria de Geografía17, 165-188.

Montibeller, G. (2004). O mito do desenvolvimento sustentável. Meio ambiente e custossociais no moderno sistema produtor de mercadorias. Florianópolis: UFSC.

MoCaSE-VC (14 de octubre de 2012). Sobre el asesinato de Miguel Galván. Recuperado de http://mocasevc.blogspot.com.ar/2012/10/sobre-el-asesinato-de-miguel-galvan.html

Patel, R. (2008).Obesos y famélicos. El impacto de la globalización en el sistema alimentario mundial. Barcelona: Los Libros del Lince.

Paruelo, J. M., Guerschman, J. P., y Verón, S. R. (2005). Expansión agrícola y cambios en el uso del suelo. Ciencia Hoy 87, 14-23.

Pengue, W. (2005). Agriculturización industrial y transnacionalización en América Latina ¿La transgénesis de un continente? Buenos Aires: PNUMA-GEPAMA.

Peremulter, T. (04 de septiembre de 2012). ¿Qué hay detrás de la nueva ley de semillas?. Marcha. Recuperado de http://www.marcha.org.ar/1/index.php/nacionales/94-ambiental/2009-que-hay-detras-de-lanueva-ley-de-semillas

Pierri, N. (2001). El proceso histórico y teórico que conduce a la propuesta de desarrollo sustentable. En Pierri, N. y Foladori, G. (Ed.). ¿Sustentabilidad? Desacuerdos sobre el desarrollo sostenible. 27-81. Montevideo: Trabajo y Capital.

Puechagut, M. S. (2012). Expansión y rentabilidad agrícola en la posconvertibilidad, Voces en el Fénix 12. Recuperado de http://www.youblisher.com/p/263232-Voces-en-el-Fenix-N-12-Rebelion-en-la-granja/

REDAF (2012). Conflictos sobre tenencia de tierra y ambientales en la región del Chaco argentino. Recuperado de http://redaf.org.ar/wp-content/uploads/2012/12/3\%C2\%BA-Informe-Conflictos-Tierra-yAmbiente.pdf

Seoane, J. (2012). Neoliberalismo y ofensiva extractivista. Actualidad de la acumulación por despojo, desafíos de Nuestra América. Theomai 26. 
Silvetti, F., Soto, G., Cáceres, D. y D. Cabrol (2013). ¿Por qué la legislación no protege los bosques nativos de Argentina? Conflictos socioambientales y políticas públicas. Mundo Agrario, 13 (26).

Svampa, M. (2012). Consenso de los commodities, giro ecoterritorial y pensamiento crítico en América Latina. OSAL, XIII (32), 15-38.

Teubal, M. y T. Palmisano (2010). El conflicto agrario: características y proyecciones. En Giarracca, N. y Teubal, M. (Coord.), Del paro agrario a las elecciones de 2009. Tramas, reflexiones y debates. Buenos Aires: Antropofagia.

Teubal, M. (2009). Expansión de la soja transgénica en Argentina. En Pérez M. (comp.), Promesas y peligros de la liberalización del comercio agrícola: Lecciones desde América Latina. La Paz: AIPE-GDAE.

Teubal, M. (2003). Soja transgénica y crisis del modelo agroalimentario argentino. Realidad Económica, 196, 52-74.

Teubal, M. (2001). Globalización y nueva ruralidad en América Latina. En Giarracca N. (comp.) ¿Una nueva ruralidad en América Latina?, 45-65. Buenos Aires: CLACSO.

Tort, M. I. (2004). La expansión de la soja: un estudio de caso. En Documentos del CIEA, 2, 41-53. Buenos Aires: CIEA.

Varesi, G. Á. (2016). Acumulación y hegemonía en Argentina durante el kirchnerismo. Problemas del Desarrollo. 47(187), 63-87. Recuperado de http://www.sciencedirect.com/science/article/pii/S0301703616300384 